\title{
PHYSICOCHEMICAL EVALUATION OF SOME NEW SOFT SEEDLING STRAINS AND LOCAL CULTIVARS OF DATE (Phoenix dactylifera L.) FRUITS UNDER THE CONDITIONS OF THE NORTH DELTA, EGYPT
}

\author{
OMAR, A. K. ${ }^{1,2^{*}}$ - El-Morshedy, F. A. ${ }^{1}$ - MAZROU, Y. S. ${ }^{3,4}-$ ABDALlah, S. S. ${ }^{1}$ - SALAMA, A. ${ }^{1}$ \\ ${ }^{1}$ Horticulture Dept., Faculty of Agriculture, Kafresheikh University, Kafr El-Sheikh 33516, \\ Egypt \\ ${ }^{2}$ Institute of Research and Consulting, King Faisal University, Hofuf, Kingdom of Saudi Arabia \\ ${ }^{3}$ Business Administration Dept., Community College, King Khaled University, Abha, Kingdom \\ of Saudi Arabia \\ ${ }^{4}$ Agriculture College, Tanta University, Tanta, Egypt \\ *Corresponding author \\ e-mail: alaa.omr@agr.kfs.edu.eg, akomar@kfu.edu.sa; phone: +20-109-740-8240
}

(Received $18^{\text {th }}$ Feb 2020; accepted $25^{\text {th }}$ May 2020)

\begin{abstract}
This research was conducted during 2017 and 2018 seasons on some soft seedling strains and local date palm cultivars grown under the condition of Baltim, Kafr ElSheikh Governorate (North Delta), Egypt. Twelve soft seedling strains (Limony, Elhamra, Elhelowa, Nwat Elbahr, koppy, Zenat Ahmer, Zenat Asmar, Ostora, Nwat zaghloul, Nemery, Om Makatif, and Meghal) and three local cultivars: Hayany, Samany and Araby (control) were evaluated using fruit characteristics. Results revealed that, Elhamra had the highest values of yield, bunch weight, fruit diameter, fruit and flesh weight, and flesh thickness during both seasons, while, Nemery strain seedlings recorded the highest seed diameter, seed weight, SSC, total and reducing sugars. On the other hand, Araby cultivar recorded the lowest values in fruit length, flesh weight, (Soluble solids Content (SSC)) and Hayany cv., in total and reducing sugars. This study could be recommended for marketing new soft strains seedling date palms (Elhamra and Nemery) the most desirable commercial attributes of local or international standards under North Delta district, Egypt conditions.
\end{abstract}

Keywords: parameters, firmness, bunch weight, SSC, total sugars, reducing sugars, fruit quality

\section{Introduction}

Egypt is a subtropical country which lies between $22^{\circ}$ and $31^{\circ}$ North latitudes and between $25^{\circ}$ and $35^{\circ}$ East longitudes. Winter is a mix of mild and wet (November - April) and summer is hot and dry (May - October) are suitable for the production of many field and Horticultural crops (Directorate of Intelligence, 2011). Egypt is the world first date (Phoenix dactylifera L.) producer with annual production of more than 1.7 million tones and contributing $18.3 \%$ in total world production (FAO, 2018). Dates can be classified into three types based on fruit moisture content; soft, semi-dry and dry cultivars (Selim et al., 1970). Cultivars Hayany, Samany and Araby are the main local soft date cultivars that grown in North Delta, Egypt. Biodiversity conservation of date palm is important in sustaining the various number of date cultivars in Egypt (Abdalla, 1986; Rizk et al., 2004). There are actually some date cultivars that are underutilized, which expected to be distinct or completely lost, and thereby affect date palm biodiversity in Egypt if it is not regularly maintains (Bazza, 2007). To 
simplify over view framework on the identification, description and documentation the agro-biodiversity of soft date cultivars in Egypt, systematical relationships of twenty one Egyptian soft date cultivars were described based on one hundred and three morphological attributes (Abd-El Hamed et al., 2017). Most of the cultivars identification studies are enumerative, based on local names, which vary from one place to another (Abd-Alla, 2010; Abdul-Hamid et al., 2018). These cultivars are location specific, and could be known by different names in different places. Moreover, only one name could be assigned to different cultivars in different places. This could cause ambiguity in classifying cultivars based on local names. There is no scientific characterization of cultivars to use more legitimate names that can be used to distinguish cultivars (Abd El-Baky, 2012). Most of the female cultivars are identified using fruit characteristics such as size, shape or color (Bekheet, 2013). Fruit length generally ranged from $2.80 \mathrm{~cm}$ in Aglany date to $5.92 \mathrm{~cm}$ in Zaghloul date (Mansour, 2005). Average fruit length in Bent-Aisha cultivar is about $3.69 \mathrm{~cm}$, while it reaches $5.92 \mathrm{~cm}$ in Zaghloul cultivar (Sakr et al., 2010). Abdalla et al. (1996) stated that grading of date cultivars is mainly considered on fruit physical characteristics and general appearance, as well as moisture and sugar content. Conventionally, date fruit have been used for treating diseases, such as sore throat and fever (Chao and Krueger, 2017). Fruit also inhibit and suppress several diseases.

The aim of this work is to characterize and evaluate some new soft seedling strains and compared to local cultivars of date palm using fruit characteristics under North Delta, Egypt conditions.

\section{Materials and methods}

This study was conducted during 2017 and 2018 seasons at a private orchard in Baltim district (located at North Delta region Kafr-El-Sheikh Governorate (31 ${ }^{\circ} 15^{\prime} 35^{\prime \prime}$ $\left.\mathrm{N}, 31^{\circ} 9^{\prime} 36^{\prime \prime} \mathrm{E}\right)$, Egypt. Baltim's climate is typical to the northern coastal line which is the most moderate in Egypt. It features a hot desert climate, but prevailing winds from the Mediterranean Sea greatly moderate the temperatures, making its summers moderately hot and humid while its winters mild and moderately wet (Fig. 1).

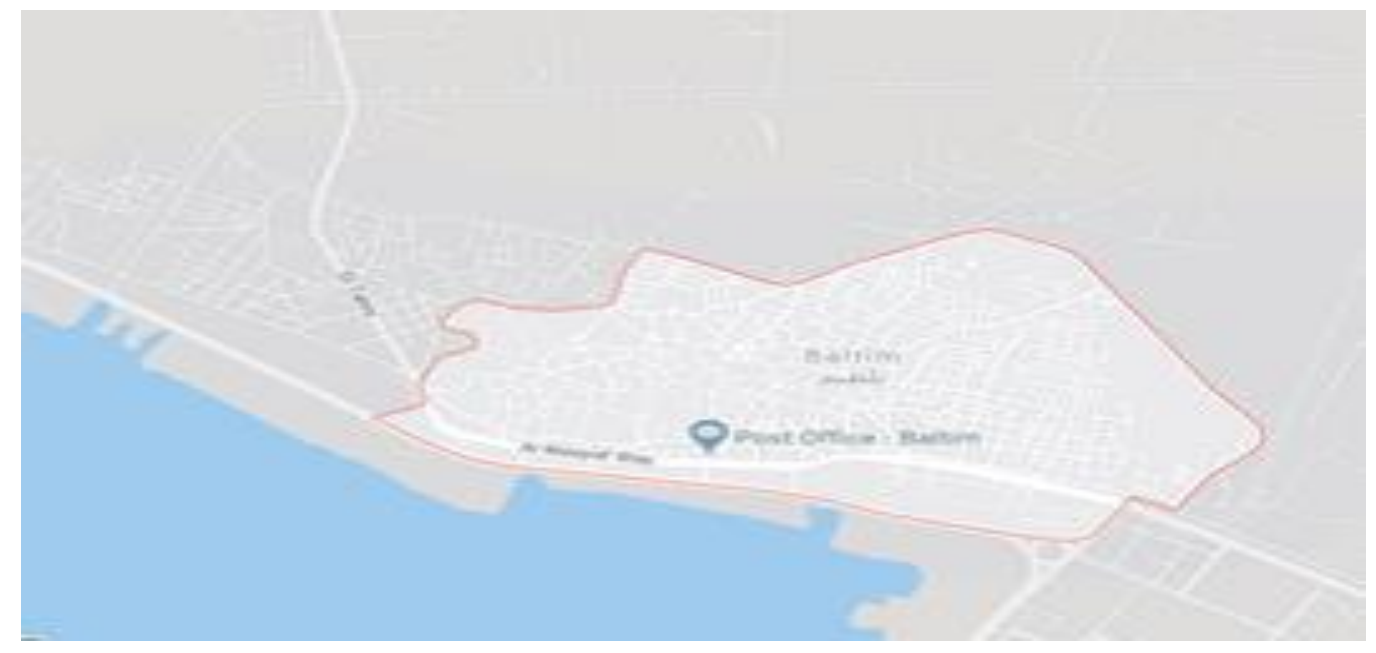

Figure 1. Baltim district, Kafr El-Sheikh, Egypt (Source: https://www.google.com/maps/place/Baltim) 
Fifteen soft seedling strains (Limony, Elhamra, Elhelowa, Nwat Elbahr, koppy, Zenat Ahmer, Zenat Asmar, Ostora, Nwat zaghloul, Nemery, Om Makatif, and Meghal) were selected from a big number of excellent seedling palms beside threes trees of local cultivars (Hayany, Samany and Araby) as a standard control. The selected palms were about 15-17 years old, grown in sandy loam soil and they characterized by high yield and fruit quality (Fig. 2).

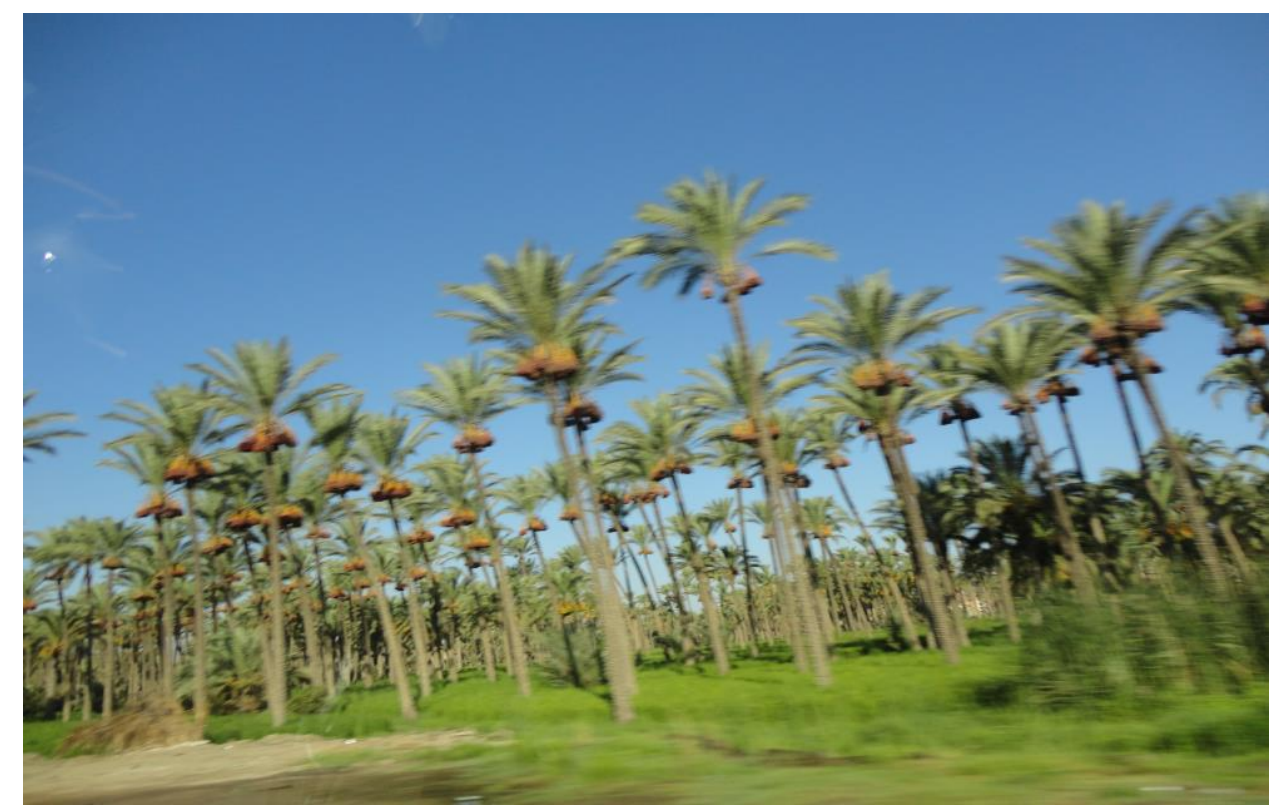

Figure 2. Experimental Orchard date palm trees in Baltim, Kafr El Sheikh Governorate, Egypt

As usual the selected palms were subjected to normal cultural practices (irrigation, fertilization, plant protections, etc.). All seedling strains and Hayany, Samany and Araby cultivars (control) were pollinated in April using pollen grains from male palm (Meghal) grown in the same location in both seasons to avoid xenia and metaxenia effects. Each of the selected tree was represented by 3 bunches as 3 replicates. Fruit samples of sixty fruit each were collected, during fruit season at Khalal (maturity) stage. Fruit weight, length, diameter, and fruit length/diameter ratio (L/D) were recorded. Same fruit were used to measure pulp and seed weight $(\mathrm{g})$, and then fruit/pulp percentage were calculated. Fruit firmness $\left(\mathrm{kg} / \mathrm{cm}^{2}\right)$ was measured at two equatorial points on the fruit using pressure tester (Penetrometer ST 308, Italy) with tips $=6.4 \mathrm{~mm}$ at $25^{\circ} \mathrm{C}$. SSC were determined according to A.O.A.C (2000) methods.. Total and reducing sugars were determined according to the methodology of Lane and Eynon described by the A.O.A.C (2000).

\section{Statistical analysis}

Experiment was designed in a randomized complete block system, and data were analyzed using analysis of variance (ANOVA) (Snedecor and Cochran, 1980). Mean comparison was carried out using Duncan multiple range test (DMART). 


\section{Results and discussion}

\section{Yield (kg/palm) parameters, bunch weight (kg/bunch) and fruit length (cm)}

Results showed that Elhamra seedling strain had the maximum yield and bunch weight recorded 200.00, 192.00, 31.00 and $29.00 \mathrm{~kg} /$ bunch, respectively during both seasons (Table 1 and Fig. 3). Elhelowa seedling strain recorded the following highest yield in both season and recorded 180.00 and $181.00 \mathrm{~kg} / \mathrm{pam}$. While Zenat Ahmer seedling strain flowed the highest bunch weight in both seasons and recorded 24.00 and $26.00 \mathrm{~kg} / \mathrm{bunch}$. On the other hand, koppy seedling strain recorded (77.00 and $76.00 \mathrm{~kg} / \mathrm{palm} ; 11.00$ and $11.00 \mathrm{~kg} / \mathrm{bunch}$ ) the lowest values in the same characters (yield and bunch weight). The longest fruit length $(6.10$ and $6.03 \mathrm{~cm})$ was recorded by Ostora seedling strain during 2017 and 2018 seasons.

Table 1. Yield parameters, bunch weight and fruit length of some new seedling strains and Samany, Araby and Hyany cultivars during 2017 and 2018 seasons

\begin{tabular}{cc|cc|cc|cc}
\hline \multicolumn{2}{r|}{ Strains/cultivars } & \multicolumn{2}{c|}{ Yield (kg/palm) } & \multicolumn{2}{c}{ Bunch weight $(\mathrm{kg} / \mathrm{palm})$} & \multicolumn{2}{c}{ Fruit length $(\mathrm{cm})$} \\
& 2017 & 2018 & 2017 & 2018 & 2017 & 2018 \\
\hline 1 & Zenat Asma & $188.67 \mathrm{~b}$ & $167.67 \mathrm{c}$ & $31.0 \mathrm{a}$ & $28.33 \mathrm{ab}$ & $4.20 \mathrm{f}$ & $4.35 \mathrm{~d}$ \\
2 & Zenat Ahmer & $187.70 \mathrm{~b}$ & $162.33 \mathrm{~d}$ & $24.00 \mathrm{~b}$ & $26.67 \mathrm{~b}$ & $4.40 \mathrm{ef}$ & $4.17 \mathrm{de}$ \\
3 & Om Makatif & $133.67 \mathrm{~d}$ & $129.00 \mathrm{~g}$ & $17.00 \mathrm{cde}$ & $15.67 \mathrm{f}$ & $5.40 \mathrm{c}$ & $5.03 \mathrm{~b}$ \\
4 & koppy & $77.00 \mathrm{~g}$ & $76.67 \mathrm{k}$ & $11.00 \mathrm{~g}$ & $11.00 \mathrm{~g}$ & $5.03 \mathrm{~d}$ & $4.60 \mathrm{c}$ \\
5 & Meghal & $161.0 \mathrm{c}$ & $155.67 \mathrm{e}$ & $23.33 \mathrm{~b}$ & $24.00 \mathrm{c}$ & $4.40 \mathrm{ef}$ & $4.68 \mathrm{c}$ \\
6 & Nwat Elbar & $122.0 \mathrm{e}$ & $180.67 \mathrm{~b}$ & $19.00 \mathrm{c}$ & $19.00 \mathrm{~d}$ & $4.33 \mathrm{ef}$ & $4.03 \mathrm{ef}$ \\
7 & Nwat zaghlou & $122.0 \mathrm{e}$ & $121.00 \mathrm{~h}$ & $16.00 \mathrm{def}$ & $16.00 \mathrm{ef}$ & $5.80 \mathrm{~b}$ & $4.68 \mathrm{c}$ \\
8 & Elhelowa & $180.33 \mathrm{~b}$ & $181.00 \mathrm{~b}$ & $29.00 \mathrm{a}$ & $29.00 \mathrm{a}$ & $5.35 \mathrm{c}$ & $4.10 \mathrm{de}$ \\
9 & Limony & $120.00 \mathrm{e}$ & $125.33 \mathrm{gh}$ & $16.00 \mathrm{def}$ & $16.00 \mathrm{ef}$ & $4.35 \mathrm{ef}$ & $4.15 \mathrm{de}$ \\
10 & Ostora & $96.00 \mathrm{f}$ & $96.00 \mathrm{i}$ & $14.03 \mathrm{f}$ & $14.67 \mathrm{f}$ & $6.10 \mathrm{a}$ & $6.03 \mathrm{a}$ \\
11 & Nemery & $90.33 \mathrm{f}$ & $91.00 \mathrm{j}$ & $18.33 \mathrm{~cd}$ & $19.33 \mathrm{~d}$ & $4.22 \mathrm{f}$ & $4.30 \mathrm{de}$ \\
12 & Elhamra & $200.00 \mathrm{a}$ & $192.33 \mathrm{a}$ & $31.03 \mathrm{a}$ & $29.00 \mathrm{a}$ & $5.03 \mathrm{~d}$ & $4.96 \mathrm{~b}$ \\
13 & Samany cv. & $138.33 \mathrm{~d}$ & $140.67 \mathrm{f}$ & $15.33 \mathrm{ef}$ & $15.00 \mathrm{f}$ & $5.03 \mathrm{~d}$ & $4.62 \mathrm{c}$ \\
14 & Araby cv. & $97.00 \mathrm{f}$ & $90.00 \mathrm{j}$ & $25.00 \mathrm{~b}$ & $24.50 \mathrm{c}$ & $4.17 \mathrm{f}$ & $3.83 \mathrm{f}$ \\
15 & Hayany cv. & $141.67 \mathrm{~d}$ & $158.33 \mathrm{de}$ & $19.00 \mathrm{c}$ & $18.00 \mathrm{de}$ & $3.55 \mathrm{~g}$ & $5.03 \mathrm{~b}$ \\
\hline
\end{tabular}

Means with the different letters within the same colume are significantly different at $\mathrm{P} \leq 0.05$ according Duncan multiple range test (DMART).

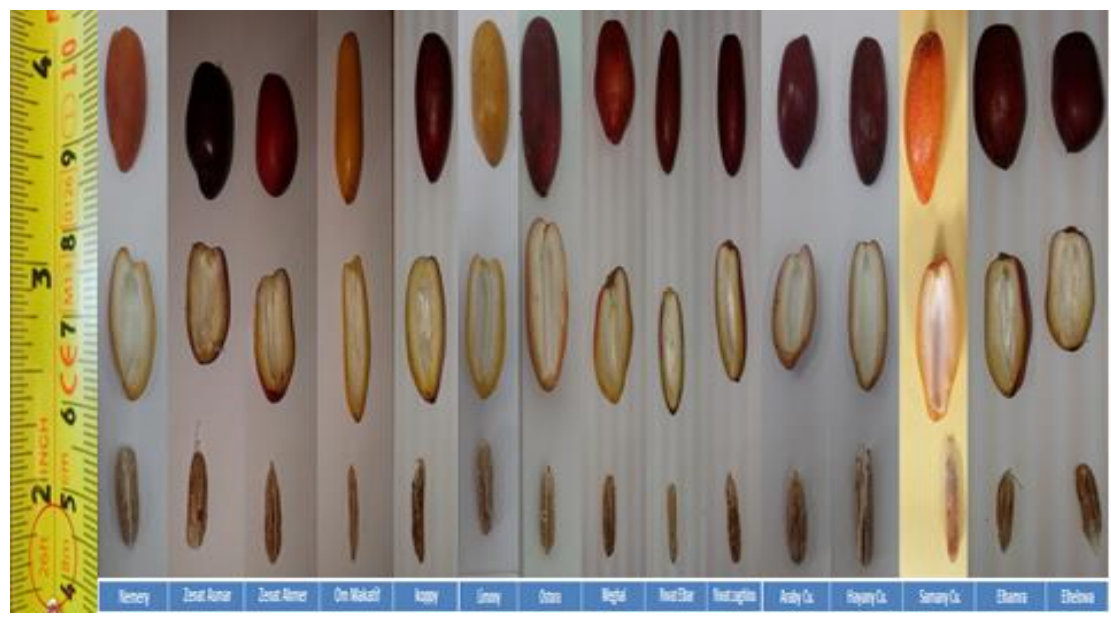

Figure 3. The fruit of selected soft seedling strains date palm \& Samany, Araby and Hyany cultivars 
Nwat zaghlou and Om Makatif seedling strains flowed the longest fruit length during 2017 and 2018 and recorded 5.80 and $5.03 \mathrm{~cm}$, respectively. While Araby cultivar recorded the shortest fruit length $(4.17$ and $3.83 \mathrm{~cm})$ during both seasons. Fruit quality is basically determined based on fruit shape, size and texture, while nutritional quality requires chemical analysis of sensory attributes (Al-Jasass et al., 2015). Results are in consistent with those of Rizk and Nahed (2006) found that Sewy cv., gave the highest yield followed by the strain Ghazal, while the strains Karama and Tagtaggt showed the lowest significant values in both seasons. Also agreement with El-Merghany et al. (2013) they found that Barhy cv., gave the highest yield/palm in the second season. El-Makhtoune and AbdelKader (1990), mentioned that the average bunch weight ranged from 4.22 to $34.40 \mathrm{~kg}$ according the date palm cultivar. Baliga et al. (2011) stated that fruit shape and organoleptic properties could indicate the differences among varieties. Habib et al. (1984), Hussein et al. (1984, 2001) and Al-Ghamdi (1996) noticed significant differences in fruit length among cultivars.

\section{Fruit diameter (cm), fruit weight and flesh weight $(\mathrm{g})$}

The weight of Fruit pulp and seed (g) are shown in Table 2 and Fig. 3. Maximum values of fruit diameter and weight, as well as pulp weight were noticed in Elhamra seedling strain by 3.60 and $4.10 \mathrm{~cm}-38.84$ and $37.27 \mathrm{~g}-33.70$ and $35.31 \mathrm{~g}$ during 2017 and 2018 seasons.

Table 2. Fruit diameter ( $\mathrm{cm}$ ), fruit weight ( $\mathrm{g}$ ), flesh weight $(\mathrm{g})$ of some new seedling strains and Samany, Araby and Hyany cultivars during 2017 and 2018 seasons

\begin{tabular}{cc|cc|cc|cc}
\hline \multirow{2}{*}{ Strains/cultivars } & \multicolumn{2}{|c|}{ Fruit diameter $(\mathrm{cm})$} & \multicolumn{2}{c|}{ Fruit weight $(\mathrm{g})$} & \multicolumn{2}{c}{ Flesh weight $(\mathrm{g})$} \\
& & 2017 & 2018 & 2017 & 2018 & 2017 & 2018 \\
\hline 1 & Zenat Asma & $2.99 \mathrm{c}$ & $3.03 \mathrm{~cd}$ & $21.50 \mathrm{~d}$ & $20.70 \mathrm{f}$ & $18.18 \mathrm{e}$ & $27.68 \mathrm{c}$ \\
2 & Zenat Ahmer & $3.03 \mathrm{bc}$ & $2.77 \mathrm{ef}$ & $21.53 \mathrm{~d}$ & $20.87 \mathrm{f}$ & $19.43 \mathrm{~d}$ & $18.83 \mathrm{e}$ \\
3 & Om Makatif & $2.17 \mathrm{e}$ & $2.37 \mathrm{~g}$ & $18.59 \mathrm{e}$ & $16.46 \mathrm{~h}$ & $12.75 \mathrm{~h}$ & $12.31 \mathrm{j}$ \\
4 & koppy & $2.99 \mathrm{c}$ & $2.87 \mathrm{e}$ & $24.42 \mathrm{c}$ & $27.43 \mathrm{~b}$ & $22.65 \mathrm{~b}$ & $34.69 \mathrm{~b}$ \\
5 & Meghal & $3.53 \mathrm{a}$ & $2.49 \mathrm{~g}$ & $34.00 \mathrm{~b}$ & $31.84 \mathrm{~b}$ & $14.71 \mathrm{~g}$ & $14.08 \mathrm{~h}$ \\
6 & Nwat Elbar & $2.47 \mathrm{~d}$ & $2.33 \mathrm{~g}$ & $24.52 \mathrm{c}$ & $21.20 \mathrm{f}$ & $17.27 \mathrm{f}$ & $17.60 \mathrm{f}$ \\
7 & Nwat zaghlou & $2.60 \mathrm{~d}$ & $2.99 \mathrm{~d}$ & $20.6 \mathrm{~d}$ & $17.75 \mathrm{~g}$ & $33.97 \mathrm{a}$ & $18.47 \mathrm{e}$ \\
8 & Elhelowa & $2.47 \mathrm{~d}$ & $2.37 \mathrm{~g}$ & $16.48 \mathrm{f}$ & $14.26 \mathrm{i}$ & $10.8 \mathrm{i}$ & $8.97 \mathrm{k}$ \\
9 & Limony & $3.17 \mathrm{bc}$ & $3.17 \mathrm{c}$ & $21.35 \mathrm{~d}$ & $22.38 \mathrm{e}$ & $19.58 \mathrm{~d}$ & $19.53 \mathrm{~d}$ \\
10 & Ostora & $3.17 \mathrm{bc}$ & $2.49 \mathrm{~g}$ & $24.87 \mathrm{c}$ & $26.60 \mathrm{~d}$ & $22.54 \mathrm{~b}$ & $16.67 \mathrm{~g}$ \\
11 & Nemery & $3.10 \mathrm{bc}$ & $3.37 \mathrm{~b}$ & $23.57 \mathrm{c}$ & $20.55 \mathrm{f}$ & $21.47 \mathrm{c}$ & $18.81 \mathrm{e}$ \\
12 & Elhamra & $3.60 \mathrm{a}$ & $4.10 \mathrm{a}$ & $38.84 \mathrm{a}$ & $37.27 \mathrm{a}$ & $33.70 \mathrm{a}$ & $35.31 \mathrm{a}$ \\
13 & Samany cv. & $3.00 \mathrm{c}$ & $3.03 \mathrm{~cd}$ & $14.89 \mathrm{~g}$ & $17.75 \mathrm{~g}$ & $18.47 \mathrm{e}$ & $18.49 \mathrm{e}$ \\
14 & Araby cv. & $2.46 \mathrm{~d}$ & $2.43 \mathrm{~g}$ & $16.47 \mathrm{f}$ & $16.21 \mathrm{~h}$ & $14.20 \mathrm{~g}$ & $12.31 \mathrm{j}$ \\
15 & Hayany cv. & $2.43 \mathrm{~d}$ & $2.68 \mathrm{f}$ & $14.69 \mathrm{~g}$ & $15.76 \mathrm{~h}$ & $13.22 \mathrm{~h}$ & $13.50 \mathrm{i}$ \\
\hline
\end{tabular}

Means with the different letters within the same colume are significantly different at $\mathrm{P} \leq 0.05$ according Duncan multiple range test (DMART).

The flowed values for fruit diameter were in Nemery seedling strain by 3.17 and $3.37 \mathrm{~cm}$, for fruit weight were 34.00 and $31.84 \mathrm{~g}$, for flesh weight were 22.65 and $34.69 \mathrm{~g}$ during both seasons. The smallest values were $2.17 \mathrm{~g}$ for fruit diameter in $\mathrm{Om}$ Makatif, $14.69 \mathrm{~g}$ in for fruit weight in Hayany cultivar, also $21.22 \mathrm{~g}$ for flesh weight in Hayany cultivar during first season. 
Results are in consistence with previous reports of Attala et al. (2001) in different date palm cultivars. Mansour (2005) recorded that fruit weight of Samany cultivar $(23.80 \mathrm{~g})$ and Bent-Aisha cultivar (11.06 g) were almost similar to our results.

\section{Seed length (cm), seed diameter (cm), seed weight (g) and flesh thickness (cm)}

The physical characters composition tests were carried out to seed length, seed diameter, seed weight and flesh thickness of various date palm seedling strains during 2017 and 2018 seasons (Table 3 and Fig. 3). Samany seedling strain recorded the smallest seed length by $2.10 \mathrm{~cm}$ in comparison to other seedling strains, Hayany had the highest values by $3.80 \mathrm{~cm}$, followed Nwat zaghlou seedling strain $(2.63 \mathrm{~cm})$ in second season. Fruit diameter was significantly different among date palm seedling strains and cultivars. Nemery seedling strain showed the highest diameter of $1.15 \mathrm{~cm}$, followed by Zenat Ahmer $(1.04 \mathrm{~cm})$ Samany $(1.00 \mathrm{~cm})$, Limony $(1.00 \mathrm{~cm})$. Result indicated that Nemery seedling strain showed the highest seed weight $(2.97 \mathrm{~g})$ followed by Samany ( $2.39 \mathrm{~g})$, while, Nwat Elbar seedling strain had the lowest $(0.45 \mathrm{~g})$ values in comparison with other seedling strains and cultivars. Fruit thickness was also significantly different from one strain to another. Elhamra seedling strain had the highest thickness $(1.50 \mathrm{~g})$ compared to other seedling strains and cultivars, while Om Makatif seedling strain recoreded the lowest thickness $(0.57 \mathrm{~cm})$ in fruits during both seasons. These results are in confirming the previous reports of Saeed and Yousof (2014). Average fruit length, width, and length/width ratio were similar to those reported by Shattir et al. (2002) and Sulieman et al. (2007, 2012), while flesh thickness, was little higher than values reported by Sulieman et al. (2012) and Saeed and Yousof (2014). Rizk et al. (2004), reported that the maximum seed weight was noticed in Siwy cultivar, while the lowest values were found in Freahy cultivar.

Table 3. Seed length (cm), seed diameter $(\mathrm{cm})$, seed weight and flesh thickness ( $\mathrm{cm})$ of some new seedling strains and Samany, Araby and Hyany cultivars during 2017 and 2018 seasons

\begin{tabular}{|c|c|c|c|c|c|c|c|c|c|}
\hline \multirow{2}{*}{\multicolumn{2}{|c|}{ Strains/cultivars }} & \multicolumn{2}{|c|}{ Seed length (cm) } & \multicolumn{2}{|c|}{ Seed diameter $(\mathrm{cm})$} & \multicolumn{2}{|c|}{ Seed weight (g) } & \multicolumn{2}{|c|}{ Flesh thickness $(\mathrm{cm})$} \\
\hline & & 2017 & 2018 & 2017 & 2018 & 2017 & 2018 & 2017 & 2018 \\
\hline 1 & Zenat Asma & $2.83 \mathrm{bcd}$ & 2.63defgh & $0.97 \mathrm{abcd}$ & $1.00 \mathrm{abc}$ & $2.37 \mathrm{ab}$ & $2.28 \mathrm{ab}$ & $0.90 \mathrm{bc}$ & $0.80 \mathrm{bcde}$ \\
\hline 2 & Zenat Ahmer & $3.20 \mathrm{abc}$ & $2.50 f g h$ & $1.04 \mathrm{ab}$ & $1.03 \mathrm{ab}$ & $2.01 \mathrm{ab}$ & $1.79 \mathrm{ab}$ & $1.03 \mathrm{bc}$ & $0.70 \mathrm{de}$ \\
\hline 3 & Om Makatif & $3.17 \mathrm{abc}$ & 2.57efgh & $0.83 \mathrm{bcd}$ & $1.00 \mathrm{abc}$ & $1.59 \mathrm{~b}$ & $1.91 \mathrm{ab}$ & $0.57 \mathrm{~d}$ & $0.63 \mathrm{e}$ \\
\hline 4 & koppy & $3.20 \mathrm{abc}$ & $2.33 \mathrm{gh}$ & $0.80 \mathrm{bcd}$ & $0.83 \mathrm{bcd}$ & $2.09 \mathrm{ab}$ & $1.90 \mathrm{ab}$ & $1.00 \mathrm{bc}$ & $1.03 b c$ \\
\hline 5 & Meghal & $3.10 \mathrm{abc}$ & $2.93 \mathrm{cdef}$ & $1.07 \mathrm{ab}$ & $0.86 \mathrm{bcd}$ & $2.24 \mathrm{ab}$ & $2.57 \mathrm{a}$ & $1.00 \mathrm{bc}$ & $0.77 \mathrm{cde}$ \\
\hline 6 & Nwat Elbar & $2.80 \mathrm{~cd}$ & $3.03 \mathrm{cde}$ & $0.70 \mathrm{~d}$ & $0.53 \mathrm{e}$ & $0.59 \mathrm{c}$ & $0.45 \mathrm{c}$ & $0.77 \mathrm{~cd}$ & $0.97 \mathrm{bcd}$ \\
\hline 7 & $\begin{array}{c}\text { Nwat } \\
\text { zaghlou }\end{array}$ & $3.20 \mathrm{abc}$ & $2.63 \mathrm{ab}$ & $0.83 \mathrm{bcd}$ & $0.87 \mathrm{bcd}$ & $2.19 \mathrm{ab}$ & $2.19 \mathrm{ab}$ & $0.97 \mathrm{bc}$ & $0.87 \mathrm{bcde}$ \\
\hline 8 & Elhelowa & $2.40 \mathrm{ef}$ & $2.80 \mathrm{cdefg}$ & $0.73 \mathrm{~cd}$ & $0.73 d$ & $1.63 b$ & $1.28 \mathrm{~b}$ & $0.83 \mathrm{~cd}$ & $0.73 \mathrm{cde}$ \\
\hline 9 & Limony & $3.27 \mathrm{ab}$ & $3.60 \mathrm{ab}$ & $0.97 \mathrm{abcd}$ & $1.00 \mathrm{abc}$ & $1.77 \mathrm{~b}$ & $1.96 \mathrm{ab}$ & $1.03 \mathrm{bc}$ & $1.07 \mathrm{~b}$ \\
\hline 10 & Ostora & $2.57 \mathrm{de}$ & $2.27 \mathrm{~h}$ & $0.97 \mathrm{abcd}$ & $0.80 \mathrm{~cd}$ & $2.13 \mathrm{ab}$ & $2.47 \mathrm{a}$ & $1.13 \mathrm{ab}$ & $0.73 \mathrm{cde}$ \\
\hline 11 & Nemery & $2.23 \mathrm{ef}$ & $3.10 \mathrm{~cd}$ & $1.15 \mathrm{a}$ & $1.10 \mathrm{a}$ & $2.97 \mathrm{a}$ & $2.49 a$ & $0.83 \mathrm{~cd}$ & $0.77 \mathrm{cde}$ \\
\hline 12 & Elhamra & $3.03 \mathrm{abc}$ & $2.80 \mathrm{cdefg}$ & $0.70 \mathrm{~d}$ & $0.93 \mathrm{abcd}$ & $2.01 \mathrm{ab}$ & $2.27 \mathrm{ab}$ & $1.30 \mathrm{a}$ & $1.50 \mathrm{a}$ \\
\hline 13 & Samany cv. & $2.10 \mathrm{f}$ & $2.20 \mathrm{~h}$ & $1.00 \mathrm{abc}$ & $1.00 \mathrm{abc}$ & $2.11 \mathrm{ab}$ & $2.39 \mathrm{a}$ & $1.17 \mathrm{ab}$ & $1.03 b c$ \\
\hline 14 & Araby cv. & $2.33 \mathrm{ef}$ & $3.27 b c$ & $0.90 \mathrm{abcd}$ & $0.83 \mathrm{bcd}$ & $2.39 \mathrm{ab}$ & $1.51 \mathrm{ab}$ & $0.80 \mathrm{~cd}$ & $0.73 \mathrm{cde}$ \\
\hline 15 & Hayany cv. & $3.33 \mathrm{a}$ & $3.80 \mathrm{a}$ & 0.90abcd & $0.83 \mathrm{bcd}$ & $1.77 \mathrm{~b}$ & $1.79 \mathrm{ab}$ & $0.57 \mathrm{~d}$ & 0.73 cde \\
\hline
\end{tabular}

Means with the different letters within the same colume are significantly different at $\mathrm{P} \leq 0.05$ according Duncan multiple range test (DMART). 


\section{Firmness $\left(\mathrm{kg} / \mathrm{cm}^{2}\right)$, SSC (\%), total and reducing sugars (\%)}

Fruit, firmness $\left(\mathrm{kg} / \mathrm{cm}^{2}\right), \mathrm{SSC}$, total and reducing content (\%) were shown in Table 4 and Fig. 3. Maximum fruit firmness was noticed in Samany seedling strain by 950.00 , while for SSC, total and reducing percentages were in Nemery seedling strain by $39.97,46.33$ and $35.00 \%$ for SSC percentages, respectively. Hayany cultivar recorded the followed value $\left(893.33 \mathrm{~kg} / \mathrm{cm}^{2}\right)$ in fruit firmness, Nwat Elbar seedling strain in SSC percentage $30.53 \%$ and Nwat zaghlou seedling strain in total and reducing sugars in 39.6 and $29.33 \%$, respectively. The smallest values were $100.00 \mathrm{~kg} / \mathrm{cm}^{2}$ for fruit firmness in Om Makatif seedling strain, for SSC was $18.83 \%$ in Araby cultivar, 27.00 and $16.60 \%$ for total and reducing sugars in Hayany cultivar, respectively. Fruit chemical characteristics have been reported by Attala et al. (2001), Al-Eid (2006), Al-Farsi et al. (2007), Alkhateeb (2008), El-Sohaimy and Hafez (2010) and El-Merghany and Zaen El-Daen (2013). The results are in agreement with many researchers such as Gadalla et al. (2013), Idris et al. (2014), Mortazavi et al. (2015), Nasir et al. (2015), El-Salhy et al. (2016), Qadri et al. (2016), Abd-El Hamed et al. (2018) reported that Barhy at khalal stage gave the lowest total sugars percentage (51 and 50\%) in both season. Youssef et al. (1998) found that total sugars concentration in fruits of eight date palm cultivars (from different areas in south Egypt) were ranged between 73.65 and $81.77 \%$ for dry cultivars. Saeed et al. (2015) stated that fruit chemical analysis of five cultivars showed that the majority of date cultivars was soft and characterized by the dominance of reducing sugars. El-Merghany, and Zaen El-Daen (2013) studied some date cultivars grown under Toshky region conditions. Seven date palm cultivars were evaluated and classified to two groups: dry date palm cultivars (Sakkoty, Bartamoda, Gondela, Malkaby and Balady [Maghal]) and soft date palm cultivars (Barhee and Sokkary). Sokkary (soft date palm cultivar) gave the highest reducing sugars (\%) in the two seasons. Evaluation study revaluated that Sakkoty and Bartamoda were the best dry date palm cultivars. Wherever, Sokkary cultivar was the best soft date palm cultivars growing under Toshky conditions.

Table 4. Firmness $\left(\mathrm{kg} / \mathrm{cm}^{2}\right)$, SSC (\%), total and reducing sugars (\%) of some new seedling strains and Samany, Araby and Hyany cultivars during 2017 and 2018 seasons

\begin{tabular}{|c|c|c|c|c|c|c|c|c|c|}
\hline \multirow{2}{*}{\multicolumn{2}{|c|}{ Strains/cultivars }} & \multicolumn{2}{|c|}{ Firmness $\left(\mathrm{kg} / \mathrm{cm}^{2}\right)$} & \multicolumn{2}{|c|}{$\mathrm{SSC}(\%)$} & \multicolumn{2}{|c|}{ Total sugars (\%) } & \multicolumn{2}{|c|}{ Reducing sugars (\%) } \\
\hline & & 2017 & 2018 & 2017 & 2018 & 2017 & 2018 & 2017 & 2018 \\
\hline 1 & Zenat Asma & $253.33 \mathrm{~h}$ & $843.33 c$ & $28.90 \mathrm{bc}$ & $28.07 \mathrm{~b}$ & $38.00 \mathrm{~b}$ & $36.67 \mathrm{bcd}$ & $28.67 \mathrm{~b}$ & $26.67 \mathrm{bcde}$ \\
\hline 2 & $\begin{array}{l}\text { Zenat } \\
\text { Ahmer }\end{array}$ & $620.00 \mathrm{e}$ & $626.67 f$ & $27.93 c$ & $29.37 b$ & $37.33 b c$ & $36.67 \mathrm{bcd}$ & $27.00 \mathrm{bc}$ & $28.00 \mathrm{bcd}$ \\
\hline 3 & Om Makatif & $100.00 \mathrm{j}$ & $486.67 \mathrm{~g}$ & $29.73 b c$ & $29.47 b$ & $36.00 \mathrm{bcde}$ & $36.33 \mathrm{bcd}$ & $26.33 b c$ & $26.67 \mathrm{bcd}$ \\
\hline 4 & koppy & $423.33 \mathrm{~g}$ & $875.00 \mathrm{~b}$ & $27.73 c$ & $28.17 b$ & $34.33 \mathrm{cdef}$ & $34.67 \mathrm{cde}$ & $23.67 \mathrm{bcd}$ & $25.00 \mathrm{bcde}$ \\
\hline 5 & Meghal & $186.67 i$ & $710.00 \mathrm{e}$ & $28.93 b c$ & $26.69 b$ & $29.00 \mathrm{~g}$ & $30.33 \mathrm{fg}$ & 19.33de & 21.33efg \\
\hline 6 & Nwat Elbar & $650.00 \mathrm{~d}$ & $636.67 f$ & $30.53 b c$ & $29.47 \mathrm{~b}$ & $32.67 \mathrm{f}$ & 33.33def & $21.67 \mathrm{bc}$ & 23.67cdefg \\
\hline 7 & $\begin{array}{c}\text { Nwat } \\
\text { zaghlou }\end{array}$ & $770.00 \mathrm{~b}$ & $713.33 \mathrm{e}$ & $30.53 b c$ & $29.30 \mathrm{~b}$ & $38.67 b$ & $39.67 b$ & $27.67 \mathrm{~b}$ & $29.33 b$ \\
\hline 8 & Elhelowa & $493.33 \mathrm{f}$ & $710.00 \mathrm{e}$ & $27.33 c$ & $27.00 \mathrm{~b}$ & $36.00 \mathrm{bcde}$ & $35.67 \mathrm{~cd}$ & $25.33 b c$ & $26.67 \mathrm{bcd}$ \\
\hline 9 & Limony & $813.33 \mathrm{a}$ & $820.00 \mathrm{c}$ & $28.50 \mathrm{c}$ & $28.17 b$ & 33.00ef & 31.33efg & $23.67 \mathrm{bcd}$ & $21.00 \mathrm{fg}$ \\
\hline 10 & Ostora & $653.33 \mathrm{~d}$ & $650.00 \mathrm{f}$ & $29.93 b c$ & $29.50 \mathrm{~b}$ & 36.30bcd & $38.00 \mathrm{bc}$ & $27.00 \mathrm{bc}$ & $28.67 b c$ \\
\hline 11 & Nemery & $656.86 \mathrm{~d}$ & 631.67f & $39.00 \mathrm{a}$ & $39.97 \mathrm{a}$ & $46.00 \mathrm{a}$ & $46.33 a$ & $35.67 \mathrm{a}$ & $35.00 \mathrm{a}$ \\
\hline 12 & Elhamra & $440.00 \mathrm{~g}$ & $750.00 \mathrm{~d}$ & $33.40 \mathrm{~b}$ & $29.70 \mathrm{~b}$ & 34.00def & $34.33 \mathrm{cde}$ & $27.00 \mathrm{bc}$ & $24.00 \mathrm{cdefg}$ \\
\hline 13 & Samany cv. & $814.33 a$ & $950.00 \mathrm{a}$ & $25.27 \mathrm{c}$ & $22.43 b c$ & $32.00 \mathrm{f}$ & 33.00def & $21.83 \mathrm{~cd}$ & 23.00defg \\
\hline 14 & Araby cv. & $736.67 \mathrm{c}$ & $750.67 d$ & $19.47 d$ & $18.83 \mathrm{c}$ & $29.00 \mathrm{~g}$ & $30.00 f g$ & $21.50 \mathrm{~cd}$ & $20.00 \mathrm{~g}$ \\
\hline 15 & Hayany cv. & $760.00 \mathrm{bc}$ & $893.33 b$ & $20.00 \mathrm{~d}$ & $21.00 \mathrm{bc}$ & $27.00 \mathrm{~g}$ & $29.00 \mathrm{~g}$ & $16.60 \mathrm{e}$ & $19.47 \mathrm{~g}$ \\
\hline
\end{tabular}

Means with the different letters within the same colume are significantly different at $\mathrm{P} \leq 0.05$ according Duncan multiple range test (DMART). 
Generally, Aseeded date palm samples characterized in this study displayed a considerable diversity for most of the selected fruit characters evaluated as compared to the control (Samany, Hayani and Eraby cvs.). Furthermore, in the present study, fruit characteristics showed significant variation among the different new seeded and cultivars samples were therefore considered as useful for the identifying particular morph-types. Morphological fruit descriptors are easy to assess and widely applied by farmers, traders, processors and consumers (Kalia et al., 2011). The results showed that, Elhamra strain had the highest values in yield, bunch weight, fruit diameter, fruit and flesh weight, and flesh thickness during both seasons. While, Nemery strain seedling recorded the highest seed diameter, seed weight, SSC, total and reducing sugars. Also, results were agreement with Morell et al. (1995), who reported that qalitative characteristics of fruit quality such as fruit shape, fruit apex and fruit stalk depth, are less prone to influences from environmental factors but are considered to be subjective to a certain extent. Baliga et al. (2011) reported that fruit shape and organoleptic characteristics can be used to differentiate between varieties. Habib et al. (1984), Hussein et al. (1984, 2001) and Al-Ghamdi (1996) noticed a significant difference in fruit dimaions and other quality parameters among date cultivars.

\section{Conclusion}

The fruit characteristics showed significant variation among the different new seeded and cultivars samples were therefore considered as useful for the identifying particular morph-types. Elhamra and Nemery strains seedling were the better compared to other indigenous cultivars studied, in terms of most physical and chemical characteristics. Elhamra seedling strain had the highest values, flowed Nemery seedling strain. Morphological fruit descriptors are wanted and easy to assess and widely applied by farmers, traders, processors and consumers (Rodríguez-Burruezo et al., 2003; Kalia et al., 2011). Even nursery operators can easily identify fruits of desired landraces suitable variety. It is concluded that Elhamra and Nemery for marketing new soft strains seedling date palms as the most desirable commercial attributes of local or international standards.

Acknowledgements. The authors extend their appreciation to the Deanship of Scientific Research at King Khalid University for funding this work through Program of Research Groups under grant number (R.G.P 2/28/40).

\section{REFERENCES}

[1] Abdalla, M. Y. (1986): Morphological and chemical studies through flowering and fruiting stages on date palm. - Ph. D. Thesis. Fac. Agric., Cairo Univ. 190p.

[2] Abdalla, M., Sabour, A., EL-Makhtoun, F., Ahmed, A. (1996): Effects of some environmental conditions on vegetative, yield and fruit properties of Sewy date cultivar. Zagazig J. Agric. Res. 23(2).

[3] Abd-Alla, M. M. (2010): Genetic stability on Phoenix dactylifera var. Karama produced in vitro. - N Y Sci J 3: 70-75.

[4] Abd El-Baky, M. A. (2012): Using morphological and anatomical features as taxonomical evidences to differentiate between some soft and semi-dry Egyptian cultivars of date palm - J Hort Sci Ornam Plants 4: 195-200. 
[5] Abd-El Hamed, K., Darwesh Rasmia, S. S., Zayed, E. M. M. (2017): Evaluation physical and chemical characteristics of some seedlings date palm fruits (Maghal) in the North Delta Egypt. - International Journal of Advances in Agricultural Science and Technology 4(7): 13-32.

[6] Abdul-Hamid, N. A., Mustaffer, N. M., Maulidiani, A., Mediani, A., Ismail, I. S., Tham, C. L., Shadid, K., Abas, F. (2018): Quality evaluation of the physical properties, phytochemicals, biological activities and proximate analysis of nine Saudi date palm fruit varieties. - Journal of the Saudi Society of Agricultural Sciences 19(2): 151-160.

[7] Al-Eid, S. M. (2006): Chromatographic separation of fructose from date syrup. - Int. J. Food Sci. Nutr. 57(1-2): 83-96.

[8] Al-Farsi, M., Al-Asalvar, C., Al-Abid, M., Al-Shoaily, K., Al-Amry, M., Al-Rawahy, F. (2007): Compositional and functional characteristics of dates, syrups and their byproducts. - Food Chem. 104(3): 943-947.

[9] Al-Ghamdi, A. S. (1996): Field evaluation of date palm (Phoenix dactylefera L.) cultivas produced through tissue culture techniques. 3- Fruit physical properties. - Bulletin of Fac. of Agric. Univ. of Cairo 47(1): 153-165.

[10] Al-Jasass, F. M., Siddiq, M., Sogi, D. S. (2015): Antioxidants activity and color evaluation of date fruit of selected cultivars commercially available in the United States. - Adv. Chem. Article ID: 567203.

[11] Alkhateeb, A. (2008): Comparison effect of sucrose and date palm syrup on somatic embryogenesis of date palm (Phoenix dactylifera L.). - Am. J. Bioche. Biotech. 4(1): 1923.

[12] AOAC. (2000): Official methods of analysis (17th edition). - Association of official analytical chemists, Arlington, VA, USA.

[13] Attala, A. M., Ibrahim, A. M., El-Kobbia, A. M. (2001): Comparative studies of leaf, pit and fruit physical and chemical characteristics of four Date Palm cultivars, 1- seasonal fluctuation of physical and chemical characteristics of pinnae. - The Fifth Arabian Horticulture Conference, Ismailia, Egypt, March 24-28.

[14] Baliga, M., Baliga, B. R., Kandathil, S. M., Bhat, H. P., Vayalil, P. (2011): A review of the chemistry and pharmacology of the date fruits (Phoenix dactylifera L.). - Food Res. Int. 44: 1812-1822.

[15] Bazza, M. (2007): Irrigated date palm production in the Near East. - Workshop on irrigation of date palm and associated crops, in collaboration with Faculty of Agriculture, Damascus University Damascus, Syria, 27-30 May.

[16] Bekheet, S. A. (2013): Date palm biotechnology in Egypt. - App Sci Rep 3: 144-152.

[17] Chao, C. T., Krueger, R. R. (2017): The Date Palm (Phoenix dactylifera L.): Overview of biology, uses, and cultivation. - Am. Soc. Hortic. Sci. 42: 1077-1082.

[18] Directorate of Intelligence. (2011): "CIA - World Fact-book". - Information on the history, people, government, economy, geography, communications, transportation, military, and transnational issues for 267 world entities. January 172013. https://www.cia. gov/library/publications/the-world-factbook/index. html.

[19] El-Makhtoun, F. M. B., Abd-El-Kader, A. M. M. (1990): Effect of different pollen types on fruit setting, yield and some physical properties of some date palm varieties. Agricultural Research Journal 68(5): 957-971.

[20] El-Merghany, S., Zaen El-Daen, E. M. A. (2013): Evaluation of some date palm cultivars grown under toshky conditions. - J. Plant Production, Mansoura Univ. 4(8): 1207-1218.

[21] El-Salhy, A. M., Ibrahim, R. A., Gadalla, E. G., Khalil, H. K. H. (2016): Evaluation of some seeded dry date palm grown under Aswan climatic condition. - Assiut J. Agric. Sci. 47(4): 136-155.

[22] El-Sohaimy, S. A., Hafez, E. E. (2010): Biochemical and Nutritional Characterizations of Date Palm Fruits (Phoenix dactylifera L.). - Journal of Applied Sciences Research 6(8): 1060-1067.

[23] FAO Statistics. (2018): http://www.fao.org/statistics/en. - Accessed on 23 July 2018. 
[24] Gadalla, E. G., Abeer, H. I., Ahmed, E. F. S. (2013): Behavior of some Egyption dry cultivars and Barhee cv. Date palm produced from tissue culture under Shark Al-Oinat condition El -Wadi El -Gadid governorate. - J of Appl. Sci. 32(12).

[25] Habib, S. S., Nawal, M. G., Nour, G. M., Hussein, A. A. (1984): Evaluation of some date palm varieties grown in North Sinai Governorate. - Agric. Res. Review. 62(3A): 277288.

[26] Hussein, A. A., Nawal, M. G., Nour Habib, S. S. (1984): Evaluation of some date palm varieties grown in South Sinai Governorate. - Agric. Res. Review. 62(3A): 289-303.

[27] Hussein, A. A. M., Attia, N. M. I., Osman, S. M. (2001): Survay and evaluation of fruit cultivars for some species grown under Siwa Oasis. II- Date palm. - Annals of Agric. Sc., Moshtohor 39(2): 1265-1278.

[28] Idris, T. I. M., Hussein, F. A., Said, A. E., Elsadig, E. H. (2014): Evaluation of some dry seedling date selections from the Northern State, Sudan. - Sudanese Journal of Agricultural Sciences 1: 30-35.

[29] Kalia, R. K., Mai, M. K., Kalia, S., Singh, R., Dhawan, A. K. (2011): Microsatellite markers: an overview of the recent progress in plants. - Euphytica 177: 309-334.

[30] Mansour, H. M. (2005): Morphological and Genetic Characterization of Some Common Phoenix dactylifera L. Cultivars in Ismailia Region. - M. Sc. Thesis Botany Department, Faculty of Science, Suez Canal University.

[31] Mortazavi, S. M. H., Azizollahi, F., Moalemi, N. (2015): Some quality attributes and biochemical properties of nine Iranian date (Phoenix dactylifera L.) cultivars at different stages of fruit development. - International Journal of Horticultural Science and Technology 2(2): 161-171.

[32] Nasir, M. U., Hussain, S., Jabbar, S., Rashid, F., Khalid, N., Mehmood, A. (2015): A review on the nutritional content, functional properties and medicinal potential of dates. Science Letters 3(1): 17-22.

[33] Qadri, R. W. K., Waheed, S., Haider, M. S., Khan, I., Naqvi, S. A., Bashir, M., Khan, M. M. (2016): Physiochemical characterization of fruits of different date palm (Phoenix dactylifera L.) varieties grown in Pakistan. - The Journal of Animal \& Plant Sciences 26(5): 1268-1277.

[34] Rizk, R. M., El-Sharabasy, Sh., El-Bana, A. (2004): Morphological Diversity of Date palm (Phoenix dactylifera L.) in Egypt. I. Dray date cultivars. - Egyptian Journal of Biotechnology 16: 482-500.

[35] Rizk, R. M., El-Sharabasy, Sh. (2004): Morphological Diversity of Date palm (Phoenix dactylifera L.) in Egypt. I.Semi dray date cultivars. - Egyptian Journal of Biotechnology 17: 218-234.

[36] Rizk, S. A., Nahed Rashed, A. K. (2006): Morphological chemical and genetical studies on some date palm cultivars and strains grown under Siwa Oasis conditions. - Egypt. J. of App. Sci. 21(8): 158-176.

[37] Rodríguez-Burruezo, A., Prohens, J., Nuez, F. (2003): Wild relatives can contribute to the improvement of fruit quality in pepino (Solanum muricatum). - Euphytica 129: 311-318.

[38] Saeed, I. K., Yousof, D. E. (2014): Nutritional changes in date fruits Barakawi cv infested by date palm dust mite Oligonychus afrasiaticus Meg. measured by physical and chemical parameters. - Persian Gulf Crop Protection 3(1): 46-51.

[39] Saeed, I. K., El-Rauof, F. A., Dawoud, H. D. (2015): Physioco-chemical evaluation of some introduced date palm fruits cultivars grown under Sudanese conditions. - Int J Appl Sci Biotechnol 3(4): 731-736.

[40] Sakr, M. M., Abu Zeid, I. M., Hassan, A. E., Baz, A-G. I. O., Hassan, W. M. (2010): Identification of some Date palm (Phoenix dactylifera) cultivars by fruit characters. Indian Journal of Science and Technology 3(3): 338-343.

[41] Selim, H. H. A., Mahdi, M. A. M., El-Hakeem, M. S. (1970): Studies on the evaluation of fifteen local date cvs grown under desert conditions in Siwa Oasis. U.A.R. - Bull. De L'Inst. Du Desert d'Egypte 38(1): 137-155. 
[42] Shattir, A. E., Abu-Goukh, A. A., Karam-Alla, K. M. (2002): Physical and chemical characteristics and yield components of 'Barakawi' and 'Gondeila' dry dates. - Sudan Journal of Scientific Research 8(1): 119-131.

[43] Snedecor, G. W., Cochran, W. G. (1980): Statistical Methods. - Oxford and J. B. H. Publishing Comm., 6th edition.

[44] Sulieman, A. E., Saleh, Z. A., Alssed, A. A. (2007): Use of Some Sudanese Local Varieties of Date Palm in Manufacturing of Date's Honey for Consumption and Exportation. - Proceedings of 4th Sypmosium on Date Palm. Al-Hassa, Saudi Arabia.

[45] Sulieman, A. E., Abd Elhafise, I. A., Abdelrahim, A. M. (2012): Comparative Study on Five Sudanese Date (Phoenix dactylifera L.) Fruit Cultivars. - Food and Nutrition Sciences 3(9): 1245-1251. DOI: 10.4236/fns.2012.39164.

[46] Youssef, M. K., El-Rify, M. N., El-Geddawy, M. A., Ramadan, B. R. (1999): Nutrient elements and vitamins content of some new valley dates and certain date products. - The international conference on Date Palm, 9-11 November, Assuit University for Environmental Studies, Egypt. 